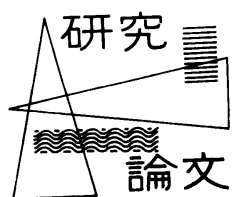

\title{
高速舶用ディーゼル機関における 低質油の燃焼と燃料噴射についで
}

\author{
末次秀雄 ${ }^{* *}$. 泉 修平 ${ }^{* * *}$. 石田正弘 ${ }^{* * * *}$ \\ 近藤 博 美 ${ }^{* * *}$ 小菅昭一郎 ${ }^{* *}$
}

\author{
Effects of Fuel Injection Mode on Residual Fuel Combustion \\ in High Speed Marine Diesel Engine
}

By Hideo Suetsugu, Shuhei Izumi, Masahiro Ishida, Hiromi Kondo, Shoichiro Kosuge

To find a basic principle of residual fuel combustion, tests were conducted on heavy fuels of $34.4 \mathrm{cSt}$ and $75.9 \mathrm{cSt}$ at $50^{\circ} \mathrm{C}\left(200\right.$ and $500 \mathrm{sec}$ RW No. 1 at $\left.100^{\circ} \mathrm{F}\right)$ using small-sized, high speed diesel engines with a cylinder bore of $110 \mathrm{~mm}$, a stroke of $125 \mathrm{~mm}$ and speeds of 2500 and $2600 \mathrm{rpm}$. Using a natural-aspirated engine, the effects of individual factors on engine performance were confirmed by changing the fuel injection mode, the cooling water temperature, the suction air flow quantity and the temperature respectively. Then using a turbocharged engine, the optimum combustion method was established by chiefly improving the fuel injection mode. Fuel combustion was evaluated by means of accurate indicator diagrams obtained by the CB-366 combustion analyzer. The reliability and durability of the engines were confirmed through thermal load analysis based on temperature measurements of the combustion chamber walls.

\section{1. まえがき}

限られた石油資源を有効飞活用するため, 舶用ディー ゼル機関において, 燃費低減という量的改善が行われて きている．しかしながら，てれ以上の燃費競争を推進す ると機関の耐久性を低下させる恐れがある。したがって， この量的改善から, 各機関が現在使用している燃料より 数段低質の燃油を実用する質的改善に移行することが必 要である.

著者らは，低質油の燃焼が困難な高速小形ディーゼル 機関を用いて, 200 秒 (RW No. 1 at $100^{\circ} \mathrm{F}$ )及び 500 秒 の重質油を燃焼する最適燃焼法の研究を行っている.

行程容積あたりの表面積が大きく，かつ許容燃焼時間 が短い高速小形機関で 200〜 500 秒の燃油を燃焼させる ことは，低速大形機関において極低質油を燃焼する場合 に相当する。着火性ならびに燃焼性の劣る低質油を良好 に燃焼させるためには，燃油の霧化や到達距離之空気の 運動及び空気量を適当に組み合わせて, 蒸発が効率良

\footnotetext{
* 原稿受付 昭和 59 年 1 月 14 日

ISME TOKYO '83 講演 (昭和 58 年 10 月 6 日)

** 正会員 長崎総合科学大学工学部 (長崎市網場町 536)

*** 正会員 長崎大学工学部 (長崎市文教町 1 - 14)

**** 長崎大学工学部 (長崎市文教町 1 - 14)

*****三菱重工業(株) 相模原製作所 (相模原市田名 3000)
}

く行われるように，油粒に充分なエネルギを与えること が重要である. このため, 供試然油の物理的, 化学的性 状を種々の方法で把握したのち, 燃焼を支配する諸要素 を個々に変化させて，それぞれの要素が機関の燃焼改善 等に及ぼす影響を正確に把握した。

\section{2. 燃料}

表 1 は, 供試油の物理化学的性質を示す. A40は粘度 40 秒の燃油で, 舶用ディーゼル油 (MDO) と同等の $\mathrm{A}$ 重 油である.

C 1500 は粘度 1500 秒の燃油であり, 大形ディーゼル 機関において広く使用されている残渣油である.

C 200 とC 500 はC1500とA40をそれぞれ 66 対 34 ， 84 対 16 の割合で混合したブレンド油である.

ADO60は, 直留系の自動車用ディーゼル軽油である.

LCGOは, 流動接触分解法によってつくられるライト サイクルガスオイルである.

図 1 は, 燃油の蒸留特性を示す. A40 は, $389^{\circ} \mathrm{C}$ でほ ば $100 \%$ 蒸発するのに対して,C 200 と 500 は, いず れ屯蒸発温度が高い上に, それぞれ $52,35 \%$ しか蒸発で きず，その残りは，燃焼室内で熱分解によって燃焼可能 な状態にするために余分の熱エネルギを供給する必要が ある。 
表 1 供試燃油の性状

\begin{tabular}{|c|c|c|c|c|c|c|}
\hline Name of Fuel & A 40 & C 1500 & $\mathrm{C} 200$ & $\mathrm{C} 500$ & ADO 60 & LCGO \\
\hline $\mathrm{Sp} / \mathrm{Gr} @ 15 / 4 \mathrm{C}$ & .8678 & .9427 & .9233 & .9358 & .8328 & .9218 \\
\hline Pour Point $\quad$ C & -2.5 & 10.0 & 5.0 & 7.5 & -10.0 & -5.0 \\
\hline Flash Point $\quad$ C & 86.0 & 110.0 & 96.0 & 98.0 & 69.0 & 88.0 \\
\hline Viscosity cSt@30 C & 5.80 & 886.0 & 85.5 & 258.0 & - & 4.35 \\
\hline $\mathrm{cSt} @ 40^{\circ} \mathrm{C}$ & - & - & - & - & 3.00 & 3.61 \\
\hline cSt@50 C & 3.84 & 170.8 & 34.4 & 75.9 & - & 3.10 \\
\hline $\begin{array}{l}\text { Surface Tension } \\
\qquad \mathrm{dyn} / \mathrm{cm}\end{array}$ & 290 & 320 & 300 & & & 290 \\
\hline C. C. R wt \% & 0.03 & $\begin{array}{l}32.0 \\
8.77\end{array}$ & $\begin{array}{l}30.0 \\
6.06\end{array}$ & $\begin{array}{l}30.5 \\
8.15\end{array}$ & $\begin{array}{l}28.0 \\
0.01\end{array}$ & $\begin{array}{l}29.0 \\
0.20\end{array}$ \\
\hline Sulfur & 0.70 & 2.55 & 1.98 & 2.24 & 0.41 & 0.70 \\
\hline wt $\%$ & 0.00 & 0.01 & 0.00 & 0.01 & - & 0.00 \\
\hline Vanadium $\quad$ ppm & $\mathrm{Nil}$ & 60 & 41 & 52 & - & $\mathrm{Nil}$ \\
\hline $\begin{array}{l}\text { Water \& Sediment } \% \\
\text { Net Calorific Value }\end{array}$ & Trace & $<0.1$ & $<0.1$ & $<0.1$ & Trace & Trace \\
\hline $\mathrm{cal} / \mathrm{g}$ & 10,150 & 9,742 & 9,845 & 9,809 & 10,350 & 9,767 \\
\hline Distillation & & & & & & \\
\hline I. B. P & 207.0 & 196.0 & 194.0 & 195.0 & 185.0 & 229.0 \\
\hline $10 \%$ & 250.0 & 284.0 & 276.0 & 276.0 & - & 264.0 \\
\hline $50 \%$ & 306.0 & - & 364.0 & - & 283.0 & 323.0 \\
\hline $90 \%$ & 380.5 & - & - & - & - & 395.0 \\
\hline $95 \%$ & - & - & - & - & 342.5 & - \\
\hline E. P. & 389.0 & - & - & - & 350.0 & - \\
\hline C. $P$. & - & $\begin{array}{l}375.0 \\
(30 \%)\end{array}$ & $\begin{array}{l}365.0 \\
(52 \%)\end{array}$ & $\begin{array}{l}370.0 \\
(35 \%)\end{array}$ & - & - \\
\hline Cetane Index & 51.8 & - & 38 & - & 60.1 & 20.0 \\
\hline $\mathrm{C} / \mathrm{H}$ Ratio $(\mathrm{g} / \mathrm{g})$ & 6.65 & 7.20 & 7.06 & 7.10 & 6.37 & 8.20 \\
\hline
\end{tabular}

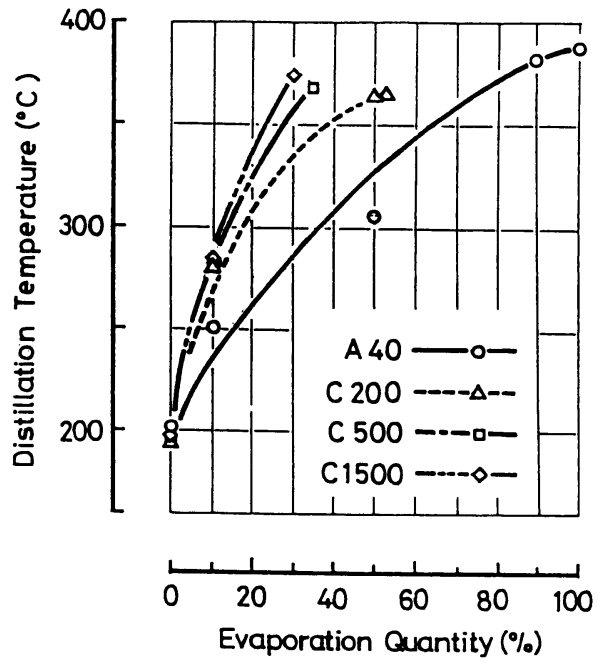

図 1 燃油の蒸留特性

図 2 は, 同一運転条件で得られた筒内圧力線図で，4 種の燃油の着火性の比較を示す。ADO35は，ADO60 とLCGOを混合して, セタン指数が 35 になるようにし たブレンド油である，C 200 における着火は，七タン指 数が 38.5 であるにあかかわらず A40 とほぼ同じである. これは，C200に含まれるA重油の影響によるあのであ る.

Journal of the M.E.S. J., Vol.20, No.5

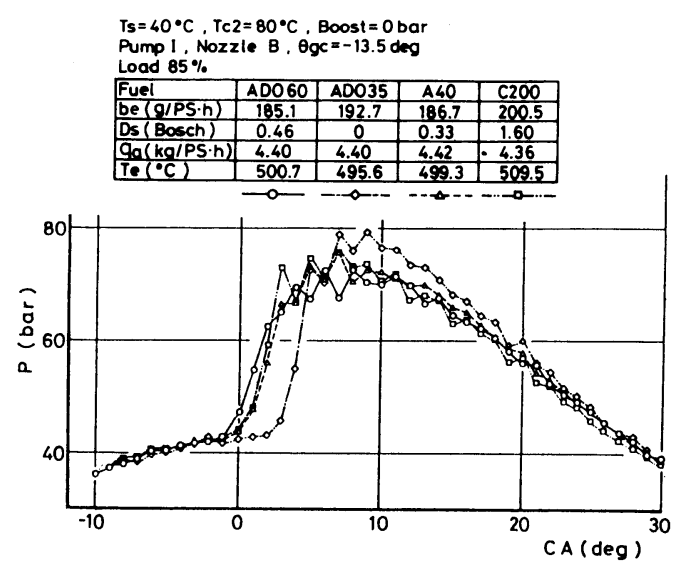

図 2 各種燃油の燃焼モードの比較

\section{3. 試験 装 置}

3.1 供試機関 供試機関として無過給タイプ (4 A -1)と過給タイプ（3AAC-1）を用いた。 これらは同一 のボアとストロークを持つ三菱重工業(株)製の直接噴射 式高速機関である。

図 3 は, 無過給機関の断面を示す. この機関は, 4 気 筒であり, 最高出力は $2600 \mathrm{rpm}$ で $70 \mathrm{~kW}(95 \mathrm{PS}$ ) であ る. この機関は空気消費率が $4 \mathrm{~kg} / \mathrm{PSh}$ 程度であり，低 質油を燃焼するには, 空気量がかなり不足している. 


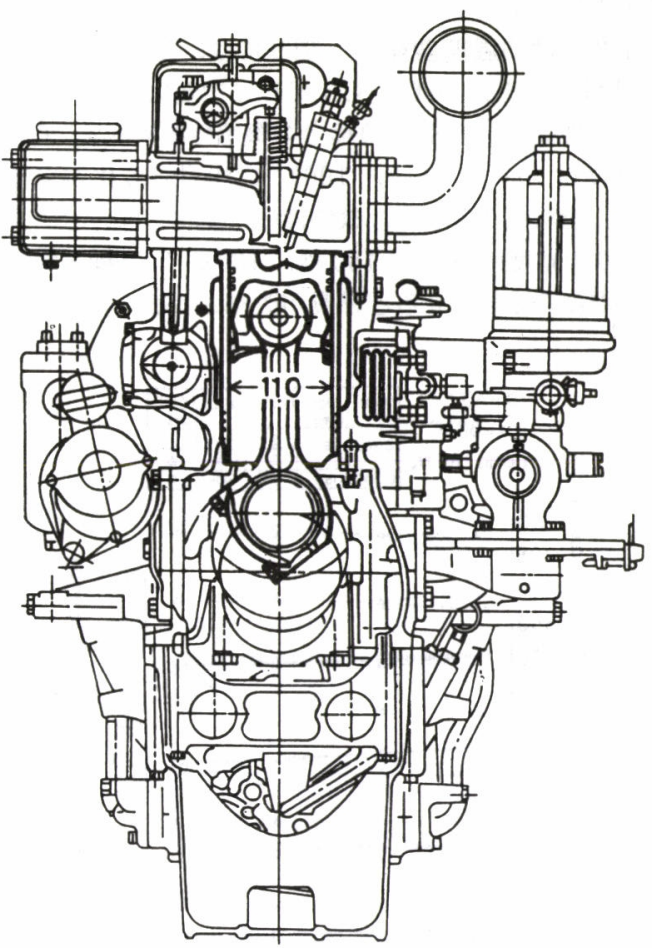

図 3 供試機関断面(無過給機関)

一方, 過給機関は 3 気筒, 最高出力は $2500 \mathrm{rpm}$ で $84.5 \mathrm{~kW}$ (115 PS) である.

3.2 燃焼試験装置困 4 は, 燃焼試験装置の系 統図を示す.

機関入口前の燃油温度と空気温度は, 設定值の $\pm 0.5^{\circ} \mathrm{C}$ 以内の精度で, 給気圧力は, \pm 0.0005 bar 以内の精度で 厳密に調整した. 機関の泠却水温度は, 機関出口におい て設定值の $\pm 0.5^{\circ} \mathrm{C}$ 以内の精度で調整した. 機関の回転数 とトルクは, $\pm 0.5 \%$ 以内の精度で調整し， 4 桁でディジ タル表示した.

図 5 には, 燃焼解析装置 $\mathrm{CB}-366$ (小野测器製)を用 いて, クランク角度 1 度毎に, 連続した 360 サイクルの 平均值として求めた指王線図を示す. 同一条件で 3 回計 測したが, 微妙な燃焼挙動についても明確な再現性が見 られる.

燃焼室壁の熱負荷を評価するために, 特に, ライナ温 度は, 無過給機関において 24 点, 過給機関において 19 点計測した. 過給機関では, 直径 $0.5 \mathrm{~mm}$ のシース熱電対 を用い, かつ, 熱電対の装着によって, 熱の流れを乱さ ないような工夫を行った. 図 6 の写真 (a) に熱電対装着 状態を,（b）にプラズマ溶射後のライナの仕上げ面を示 す.

燃焼の挙動をとらえる一方法として，2 連のマイクを 用いる音響インテンシティ法を適用し, 燃焼騒音を計測 し, 周波数ごとの騒音をエネルギとして定量的に把らえ

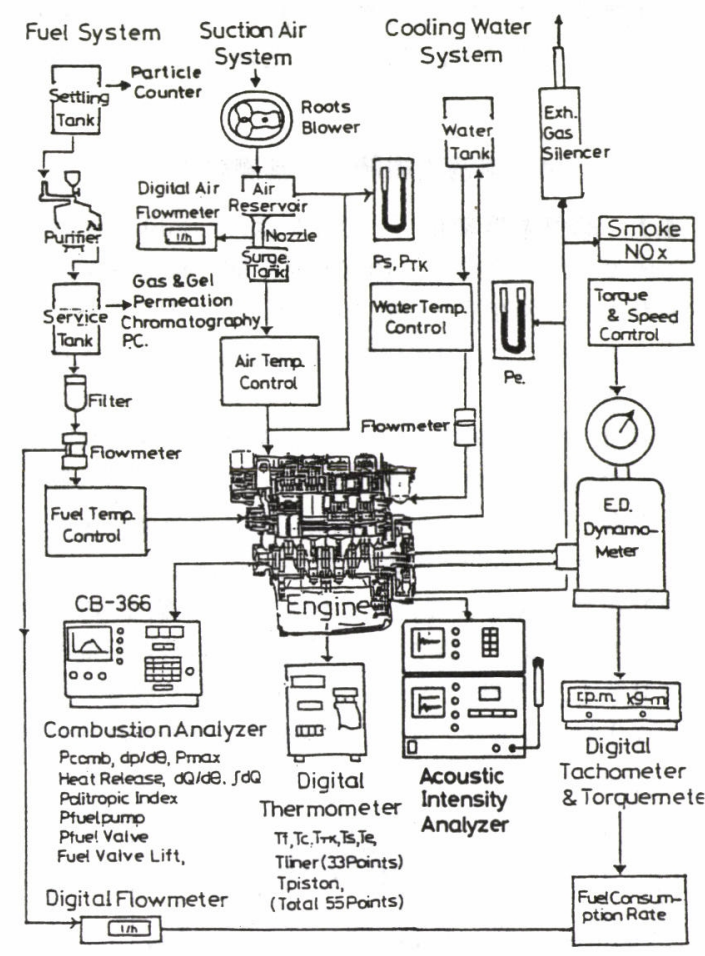

図 4 燃焼試験装置

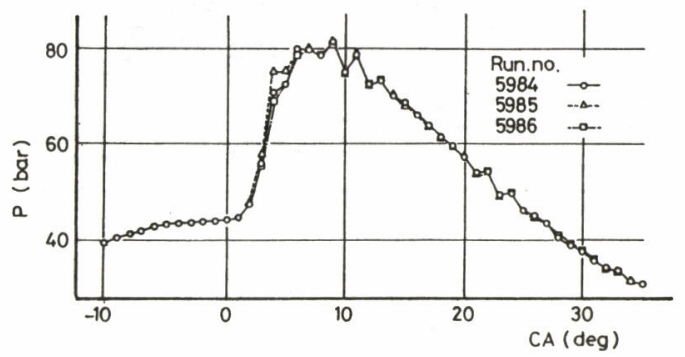

図 5 燃焼挙動の再現性

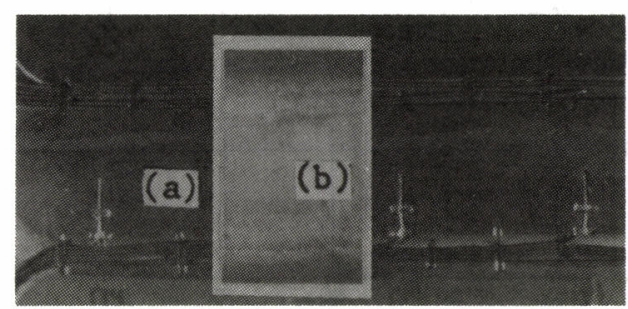

図 6 ライナ温度計測用熱電対装着状態 
た. 本実験では, 小野測器製の音響インテンシティ解析 装置 CF-502をFFTアナライザと組み合わせて用い た。

\section{4. 無過給機関での基礎試験}

4.1 給気温度変化 図7 亿は, C 200 において, 給気流量一定の条件で, 給気温度を $30 \sim 80^{\circ} \mathrm{C}$ まで変化 させたときの燃焼圧力と圧力変化率のモードを示す. 給 気温度の上昇により着火は進み, 圧力上昇率の最大值は 減少する.

図 8 は, 給気流量を一定にして, 給気温度を変化させ た場合の各種燃油の着火遅れを示す. ここで, 着火遅れ は，針弁リフトの立上がり時期から圧力が急激に上昇し 始める点までの時間と定義している，なお，ADO40 は $\mathrm{ADO} 60$ と LCGO を混合してセタン指数が約 40 になる ようにしたブレンド油である. 各燃油とも給気温度を上 昇させると，ほぼ同じ割合で着火遅れは短くなる．給気 温度を上昇させると, 着火上初期燃焼は改善されるが,

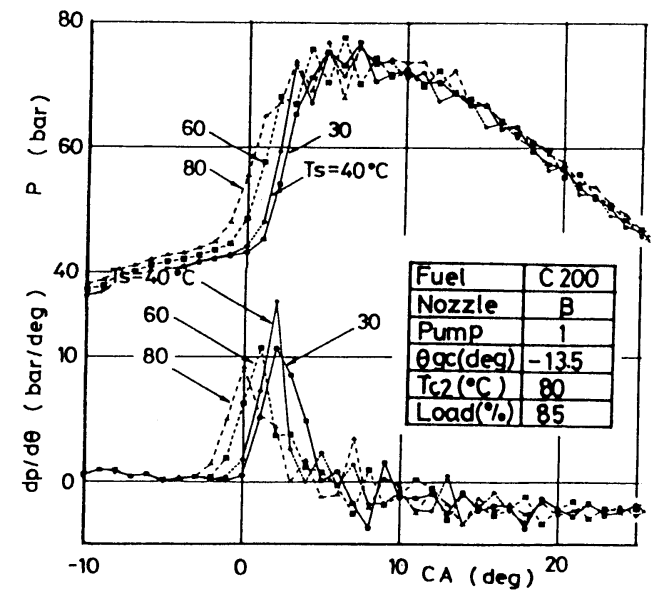

図 7 給気温度変化

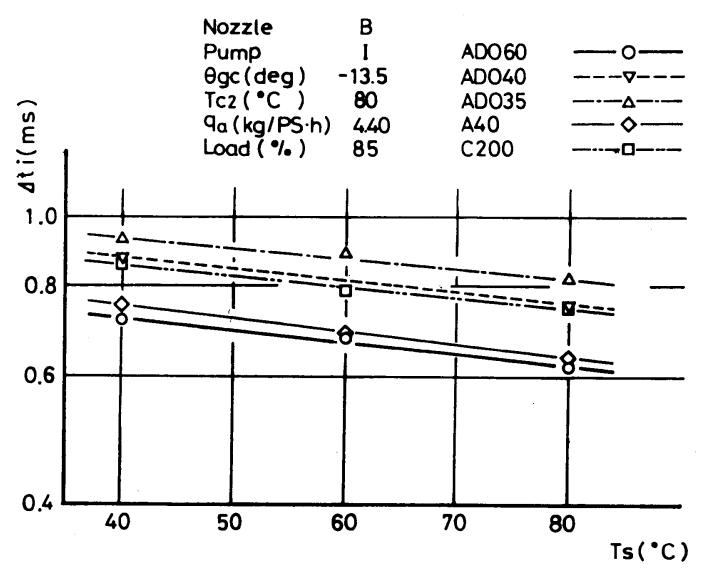

図 8 着火遅れ
主燃焼は若干悪くなる。

4.2 燃油温度変化 困 9 には, 噴射ポンプ入口 の燃料温度を， $70^{\circ} \mathrm{C}$ から $100{ }^{\circ} \mathrm{C}$ まで変化させた場合の, 舶用特性曲線上の $85 \%$ 負荷での機関性能を示す.C200 の粘度は $70^{\circ} \mathrm{C}$ で 70 秒, $100^{\circ} \mathrm{C}$ で 40 秒之変化が少ない ため，燃料消費率を含む機関性能は変化しない。一方， $\mathrm{C} 500$ の粘度は $70^{\circ} \mathrm{C}$ で 150 秒， $100^{\circ} \mathrm{C}$ で 70 秒となり， 燃油温度を上昇させると燃費が改善される。

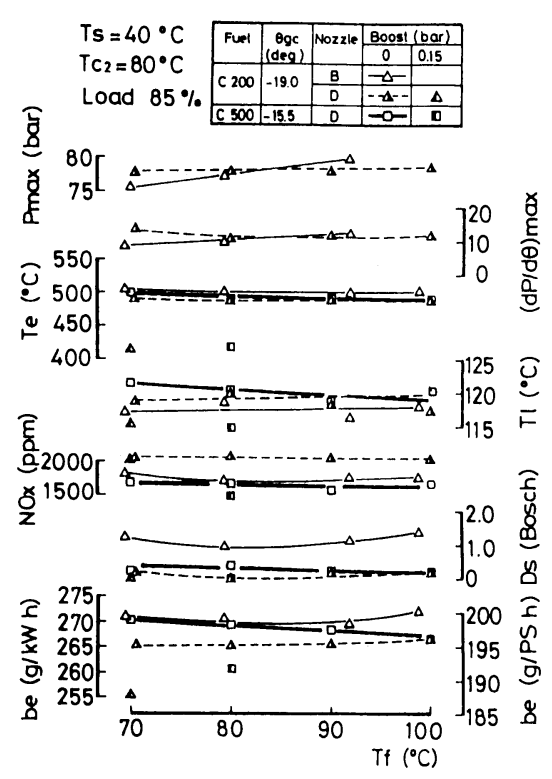

図 9 燃油温度変化

4.3 燃料噴射モード変化試験に用いた 5 種の 燃料弁を下記に示す.

$\begin{array}{ccl}\text { 燃料弁 } & \text { 噴孔径 } \times \text { 穴数 } & \text { 面積比 } \\ \text { A } & 0.31 \times 5 \text { 穴 } & 1.14 \\ \text { B } & 0.29 \times 5 & 1.0 \\ \text { C } & 0.27 \times 5 & 0.87 \\ \text { D } & 0.25 \times 5 & 0.74 \\ \text { E } & 0.22 \times 5 & 0.58\end{array}$

図 10 は, 噴孔面積比を変化させたときの舶用特性曲線 上の $100 ， 85 \%$ 負荷での噴射圧力及び機関性能を示す. 面積比で $26 \%$ 小さいD形燃料弁を使うと，噴射圧力は， 標準仕様の B 形燃料弁に比べ, $100 \%$ 負荷で $25 \%$ 高く, 85\%負荷では $27 \%$ 高くなる. その結果, $100 \%$ 負荷に おいては, 燃費の低減量は $5.4 \mathrm{~g} / \mathrm{kWh}(3.9 \mathrm{~g} / \mathrm{PSh})$, 煙濃度の低減量は 2.0 Bosch である. 面積を $42 \%$ 小さく した $\mathrm{E}$ 形では，噴射圧力は上昇するが，噴射期間が長く なるため, 燃焼が改善されない。

図 11 は, 燃料弁 B とDの噴射モードの比較を示す.

4.4 冷却水温度变化 冷却水温度を上昇させる ことによって，機関性能が改善された. $85 \%$ 負荷で, 冷 却水温度を $60^{\circ} \mathrm{C}$ から $90^{\circ} \mathrm{C}$ まで $30^{\circ} \mathrm{C}$ 上昇させたとき, 


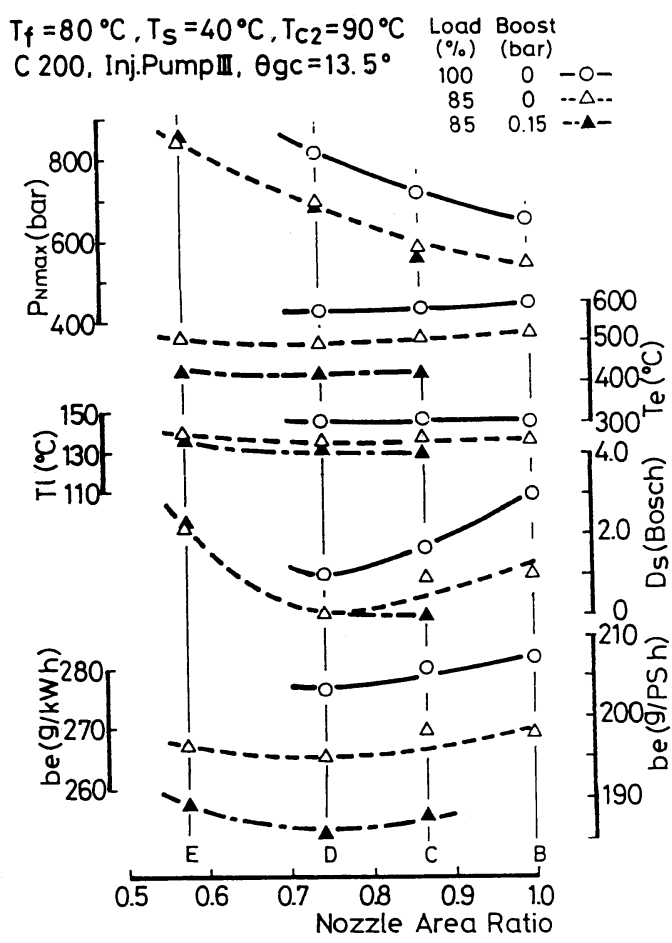

困 10 ノズル噴孔面積変化

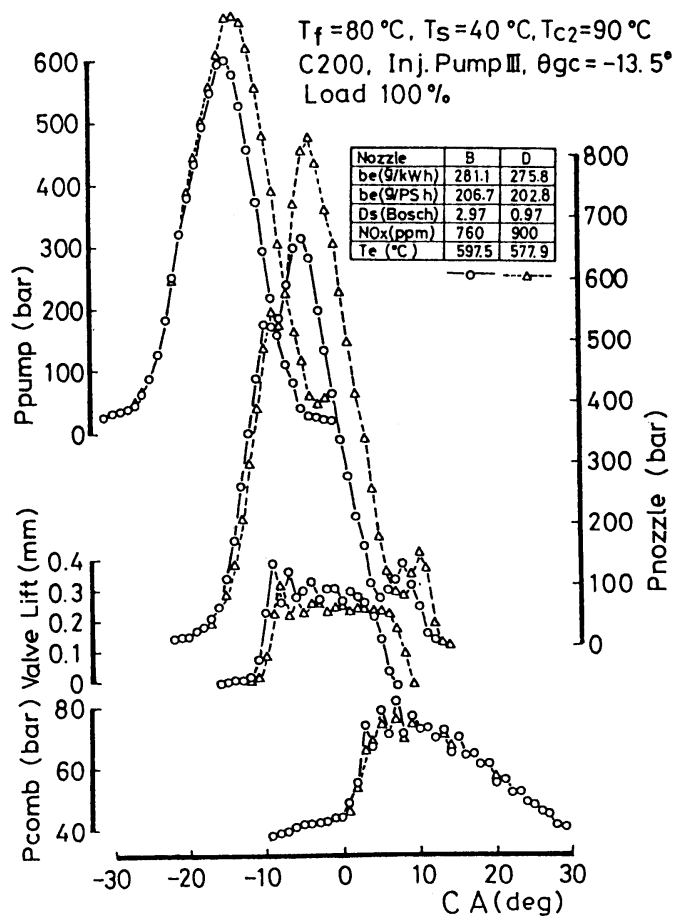

図11 ノズル変化における噴射モードの比較
$\mathrm{C} 200$ の燃費は $11.4 \mathrm{~g} / \mathrm{kWh}(8.4 \mathrm{~g} / \mathrm{PSh})$ 低減された. てれは主として冷却損失が減少するためである.

4.5 給気流量変化 いずれの燃油であ給気流量 を増大させると, 燃費, 煙濃度が著しく改善される. C 200 の場合, 給気圧力を $0.1 \mathrm{bar}$ 上昇させると空気消 費率は $12 \%$ 増加し，燃費は $8.3 \mathrm{~g} / \mathrm{kWh}(6.1 \mathrm{~g} / \mathrm{PSh}$ )低 減される。

図 12 は, 給気圧力を変化したときの $\log P-\log V$ 曲 線を示す. 図中の数字はそれぞれの区間平均のポリトロ 一プ指数で図 c の場合について示した。 0.2 bar の給気 圧力上昇により， $P_{\mathrm{mi}}$ が $6.94 \mathrm{bar}$ から $6.86 \mathrm{bar}$ となり， 機械損失が $1.2 \%$ 減少した. ポンプ損失は 0.22 bar から $0.14 \mathrm{bar}$ となり， $P_{\mathrm{mi}}$ あたりのポンプ損失が $1.2 \%$ 減少 した. このとき燃費は $4.7 \%$ 低減されたので, 上記の二 つの損失との差 $2.3 \%$ が給気流量增大による燃焼改善で ある.

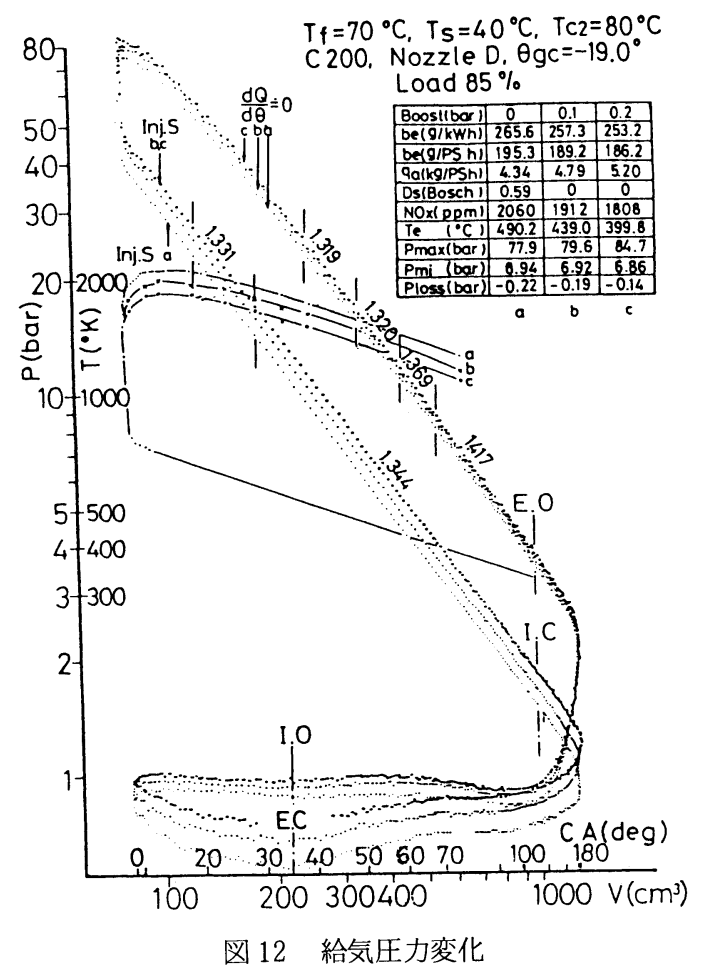

\section{6 無過給機関における燃焼試験の評価}

前述の燃焼を支配する個々の要素を組み合わせて, 低 質油 C 200 の燃焼改善を行った. 機関の耐久性について は, 燃焼室壁の詳細な温度計測により評価した.さらに, 燃焼之燃焼騒音との関連を調へ，燃焼の総合的な評価を 行った。機関性能の代表として燃費と煙濃度を図 13 亿 示す.

（1）噴射時期，噴射ポンプのプランジャ径及びカムリ フト，ならびに，噴孔径等の変更による噴射モードの適 正化 
（2）冷却水温度上昇による冷却損失の低減

（3）給気圧力上昇による油粒への熱エネルギの供給増 等の対策を行うことにより，C200の燃焼において， $\mathrm{A} 40$ と同等の值を得ている. $85 \%$ 負荷では，C200と $\mathrm{A} 40$ の当初の燃費差 $18.1 \mathrm{~g} / \mathrm{PSh}$ を上回る燃費の低減量 $18.8 \mathrm{~g} / \mathrm{PSh}$ を得た。また，広範囲のトルク及び回転数 の運転領域においても，C200 (改善)の燃費は，A40の
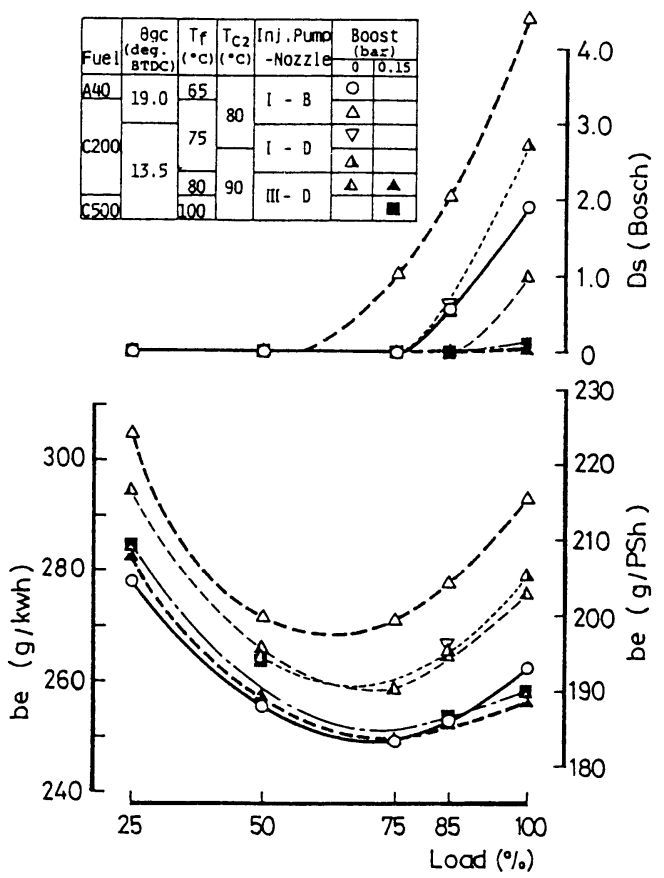

図 13 無過給機関における性能改善
それと同等であるととを確認した。なお，C500亿つい ても，C200とほぼ同じ改善対策により，C 200 に近い 燃費を得ている.

機関の信頼性を確認するための連続耐久運転において, 燃焼室壁各部の温度を計測したところ, 機関の運転条件 が十分整定しているにもかかわらず，ライナ各部の温度 が周期的に変動していることを発見した.

図 14 には, 85\%負荷での A 40 の燃焼試験中に得ら れた，第 4 気筒ガス側トップリング位置の，円周方向の 4 点におけるライナ温度の周期的変動を示す. 各点とも 2.2 分の周期で変動し, そのピーク位置は, $\mathrm{A}_{3}, \mathrm{~B}_{3}, \mathrm{C}_{3}$, $\mathrm{D}_{3}, \mathrm{~A}_{3}$ の順に移動している. 乙れは第 1 ピストンリング の合口付近からの燃焼ガスの漏洩を示すあのである. ピ ストンリングは機関上部から見て時計回り方向に回転し ている，温度変動の最大值は， $100 \%$ 負荷では $10^{\circ} \mathrm{C} に$ 達することがあり, この温度変動を考虑して, 燃焼室壁 の熱負荷を評価した.

図 15 には,トルクと回転数を広範囲に変化させたと きのガス側ライナ上端部 $\mathrm{A}_{1}$ 点のライナ温度を， $\mathrm{A} 40$ と $\mathrm{C} 200$ (改善)の場合において示す. 図中の $\mathrm{A}_{i}, \mathrm{~B}_{i}, \mathrm{C}_{i}$, $\mathrm{D}_{i}, \mathrm{E}_{i}, \mathrm{~F}_{i}, \mathrm{M}_{i}$ は㬰測点である. $\mathrm{C} 200$ (改善)の場合 は, 冷却水温度が $10^{\circ} \mathrm{C}$ 高いにあかかわらず，高卜ルク 域では，燃焼改善が著しいため，A40の場合より低い 值を示している.

図 16 には, 機関の回転数及びトルク, 給気温度 $(20$, $\left.40,80^{\circ} \mathrm{C}\right)$ 及び着火促進剂の添加率 $(2 X, 8 X: X=0.1 \%)$ をそれぞれ個々に変化させた場合の圧力上昇率の最大值 $(d P / d \theta)_{\max }$ 之機関騒音の A. I. 值 (オバーオール值) と の関係を示す. 図中の $\mathrm{B}_{i}, \mathrm{D}_{i}, \mathrm{E}_{i}$ は図 15 の実測点に対

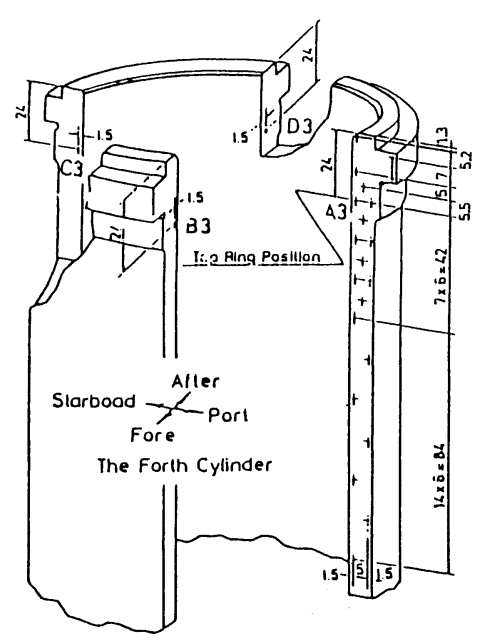

\begin{tabular}{|l|c|c|c|}
\hline Load (\%) & 85 & Tc2 & 80 \\
\hline Fue! & $A 40$ & Ts & 40 \\
\hline Ogc (deg) & -19 & Boos I(bar) & 0 \\
\hline Nozzle & 15 & & \\
\hline
\end{tabular}

Firing Order $\quad 1-3-4-2$

Rotallon Clock WIse from Fore End $T(\cdot \mathrm{C})$

A 3

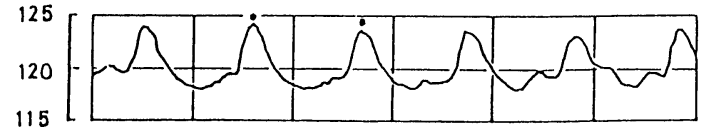

B3

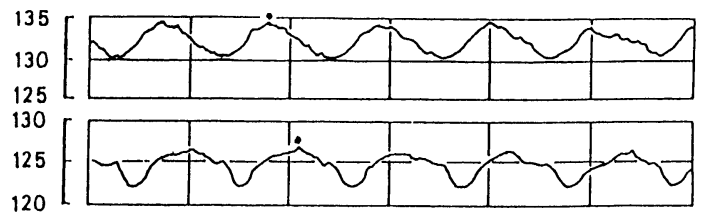

D3

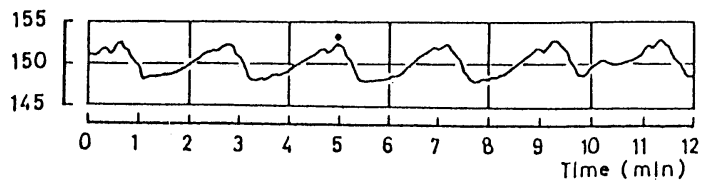

図 14 ライナ温度の周期的変動 


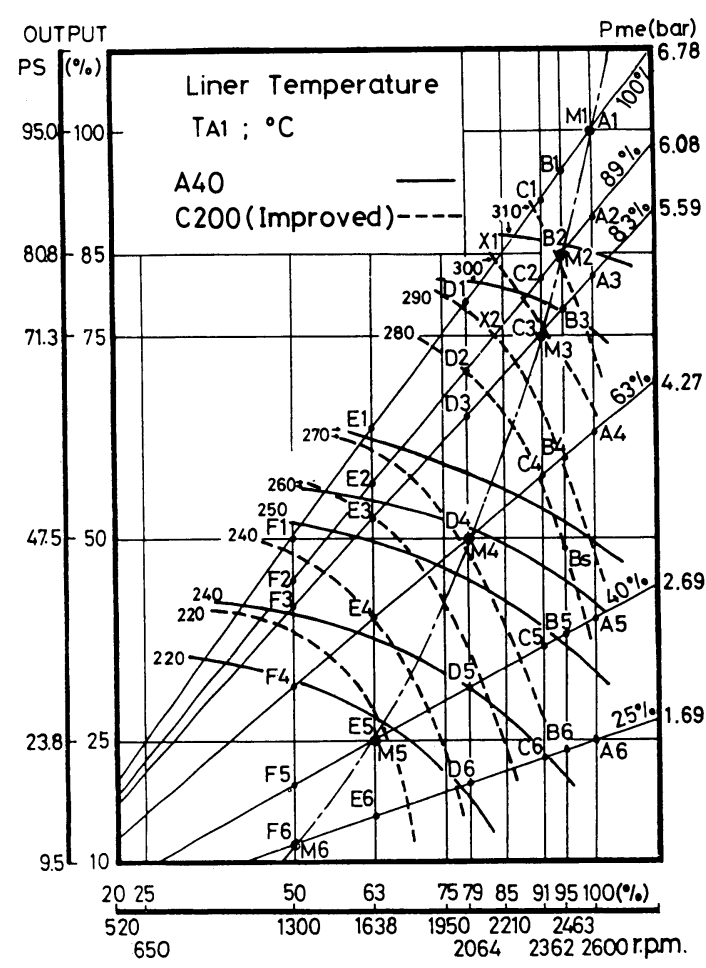

困 15 広範囲運転領域における燃焼室壁温度

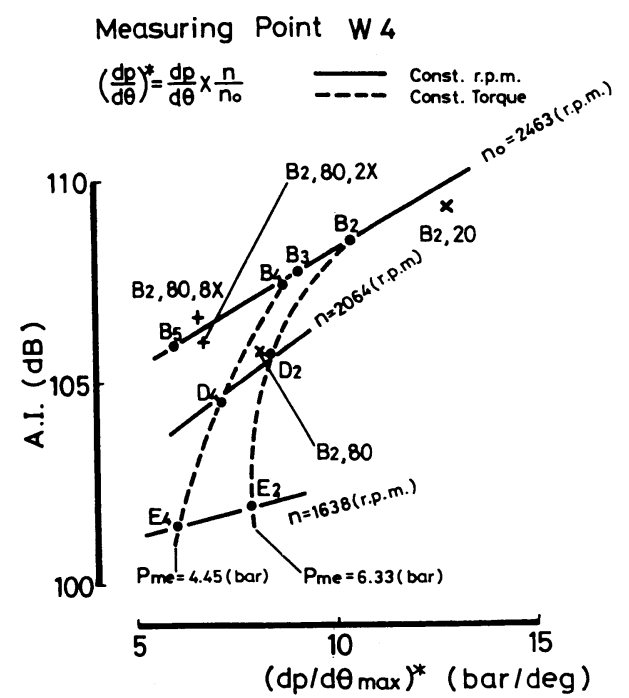

困 16 圧力上昇率と機関騒音の相関

応する、困は，第 1 気筒のある一つの計測点における計 測值であるが，それぞれの運転条件変化に対し，A.I. 值 と $(d P / d \theta)_{\max }$ は関連を持って変化している.

図 17 には，機関回転数を一定 $(2463 \mathrm{rpm})$ に保ち, ト ルクならびに給気温度を変化させたときの $(d P / d \theta)_{\max }$ とA.I. 值の相関係数を各周波数ごとに示している. 図

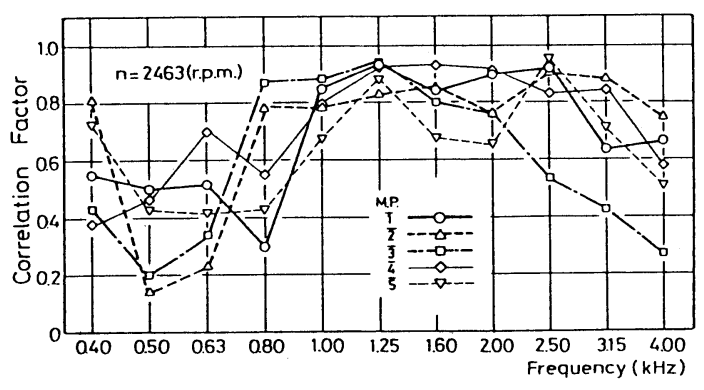

困 17 各周波数に抢ける相関係数

中の $1,2,3,4,5$ は図 3 の機関断面の上半平面において, 燃焼室を中心とした半径 $500 \mathrm{~mm}$ の半円周上を吸気側か ら排気側まで等間隔に定めた計測定で，“一”は 4 筒平 均值を意味する. $1.0 \mathrm{kHz}$ から $2.5 \mathrm{kHz}$ の間では, 全計 測点の相関係数は約 0.8 以上であり, 相関が顕著である. このように，燃焼と燃焼騒音の関係の糸口を見い出した ことは, 音響インテンシティ法が燃焼を評価するための 新しい手段となりうるととを示すあのである.

\section{5. 過給機関における燃焼試験}

無過給機関 (4 A-1) では，わずか 0.15 barの給気圧力 上昇による燃費低減量が全低减量の約 $50 \%$ を占めており, 給気流量の増大が最大の改善要素であることを示してい る. 一方, 過給機関 $(3 \mathrm{AAC}-1)$ に㧧いては, 空気流量 は満たされているので，主として，噴射モードの変化に よって燃焼改善を行った.

\section{1 燃料噴射モード}

5.1.1 噴射時期変化図 18 は, $85 \%$ 負荷におい て，噴射時期を変化させたときの噴射モード，針弁リフ ト及び燃焼モードを示す．噴射時期を遅らせると，噴射 開始時期がシフトし，それに伴って着火時期が遅れ，最 高燃焼圧力が減少する. 静的圧送開始時期 $\theta_{\mathrm{gc}}$ が $13^{\circ}$ BTDC から $7^{\circ}$ BTDC の間では燃費, 煙濃度とあほとん ど変化しないが，それ以上遅らせると急激に悪化する. 燃費, 煙濃度, 最高燃焼圧力の点から $\theta_{\mathrm{gc}}$ は $7^{\circ} \mathrm{BTDC}$ が適当と判断した.

5.1.2 噴射ポンプ及びノズル変化 噴射ポンプに 関しては，標準仕様のポンプIに比し，プランジャ径を $5 \%$ ，力ム速度を $10 \%$ 増大したポンプII と，さらに，プ ランジャ室のデッド・ボリュームを減少したポンプII （a）を使用した．燃料弁に関しては，標準仕様の燃料弁 $\mathrm{A}(\phi 0.31 \times 5)$ より噴孔面積を $24 \%$ 減じた燃料弁 C $(\phi$ $0.27 \times 5)$ を組み合わせて, 燃焼試験を行った. 図 19 は, このときの噴射モードの比較を示す. ポンプII の場合に は, 最高噴射圧力は, ポンプI のそれとほぼ同じである が，初期の圧力上昇率及び噴射圧力が高いため，燃焼が 著しく改善され，100\%負荷では, 燃費が $16.1 \mathrm{~g} / \mathrm{PSh}$ 低减している.さらに, ポンプII (a)とノズルCの組合 


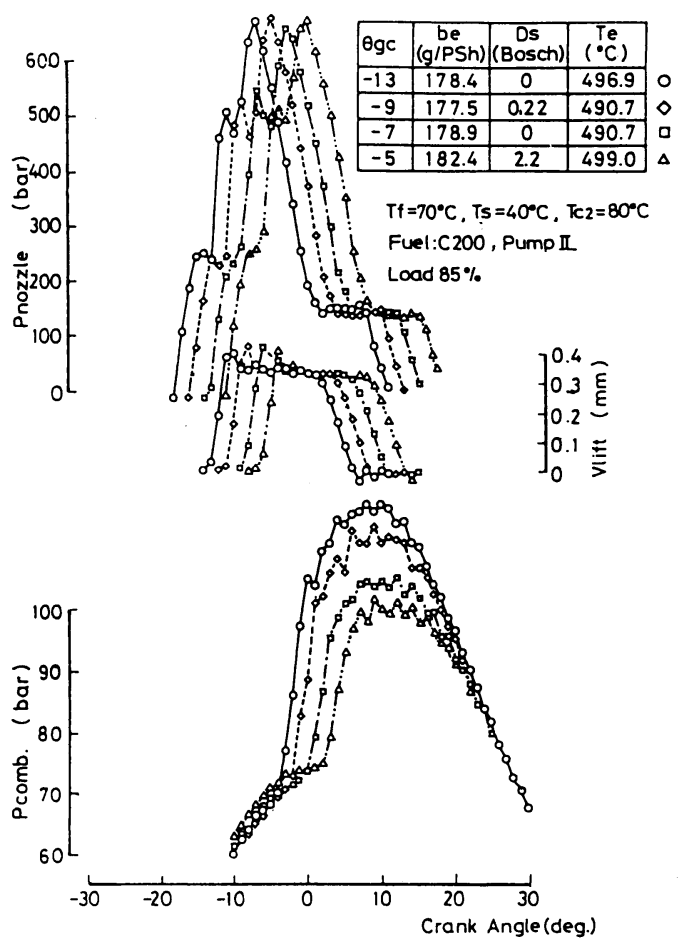

困 18 噴射時期変化

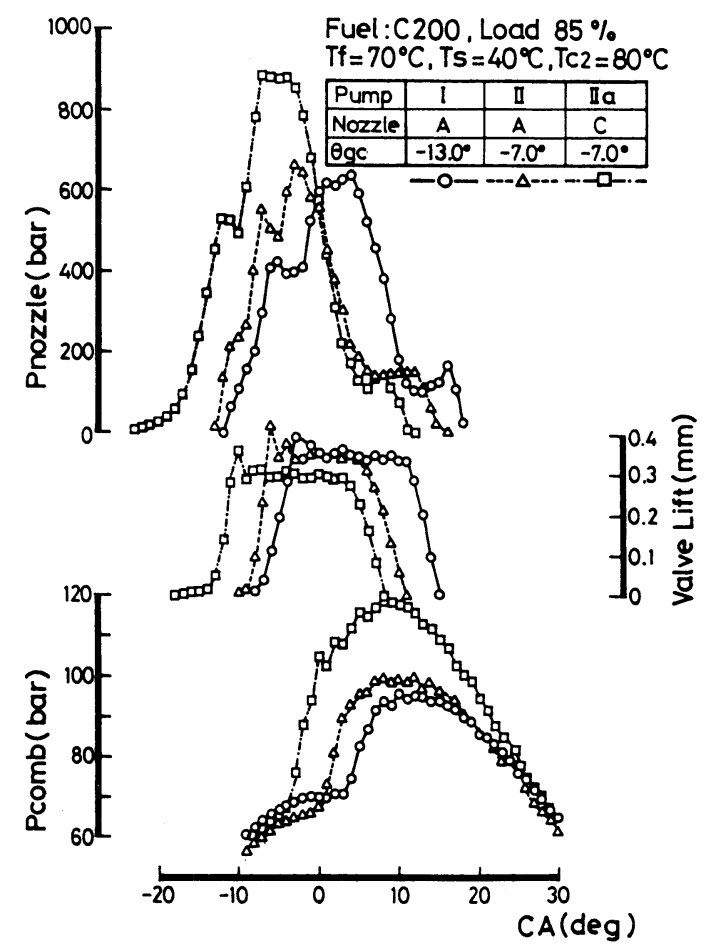

図 19 ポンプ及びノズル変化
せによって，最高噴射圧力はポンプ II に比し，33\% 増大 し, 燃費が $3.1 \mathrm{~g} / \mathrm{PSh}$ 低減された。図 20 に示すように, 噴孔面積の減少は低負荷域での燃費低減に顕著な効果を 示す.

5.2 燃焼改善の結果過給機関に対し, 燃料噴 射システムのみの改善による実用的対策を適用し，低質 油 C 200 の燃焼改善を確認した. 図 20 は, 舶用特性曲 線上の機関性能を示す. $85 \%$ 負荷では, 噴射モードの最 適化によって $16.1 \mathrm{~g} / \mathrm{PSh} の$ 燃費が低減され，乙の低減 量は燃油 C 200 が A40 に対して, 当初有していた燃費差 $15.2 \mathrm{~g} / \mathrm{PSh}$ より大きい.

C 200 の発熱量が A40 のそれより $3 \%$ 低いことを考慮 すると，舶用特性曲線上の全範囲において C 200 の燃焼 は当初の A40の燃焼より優れている.なお上記の燃費 低減量の中には背圧の低減による燃費低減量 $1.0 \mathrm{~g} / \mathrm{PSh}$ が含まれている.

機関の熱負荷を評価するため燃焼室壁の温度分布を詳 細に計測したが，その一例として，100\%負荷でのシリ ンダライナ縦断面のガス側の温度分布を図 21 に示す. 熱電対の装着方法が適切なため, 温度分布は滑らかな変 化を示し，燃焼のわずかな相違を明確に示している．燃 焼改善対策後のトップリング位. 置 $\mathrm{A}_{3}$ 点における温度は, A40 の場合とほぼ同じで，ピストンリング及びライナの 耐久性の面から考えても実用的に十分低い值である.

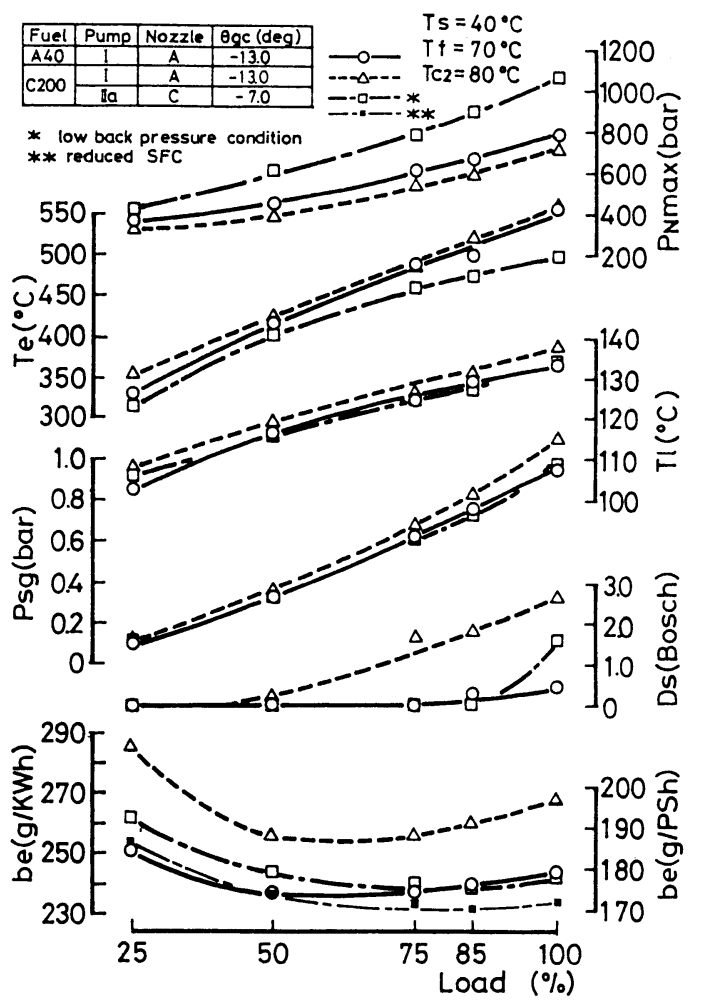

困 20 過給機関における性能改善 


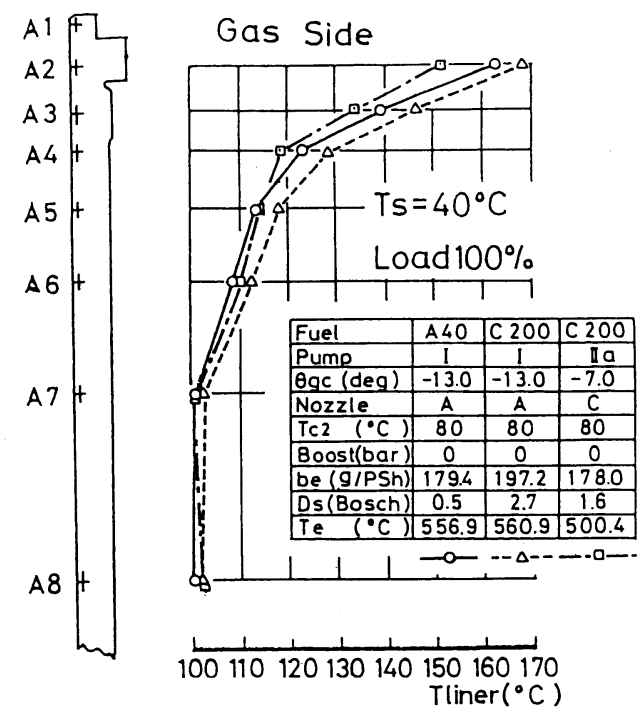

図 21 ガス側ライナ温度分布

\section{6. 結 論}

（1）無過給機関において, 低質油 C 200 を燃焼する時, 燃料噴射モード, 冷却水温度を適正に保ち, わずか 0.15 bar の給気圧力上昇を行うと, 良質油 A40 に匹敵する 良好な燃焼が得られた。

（2）過給機関では, 給気流量は十分あるので, 主とし て, 燃料噴射系の改善により十分な信頼性と耐久性のあ る良好な燃焼が確認された。

（3）一定の負荷条件では，ピストンリングが一定方向 に回転していることを発見したが，ての挙動は熱負荷を 検討する上で興味ある事実である.

（4） 2 連のマイクを用いる音響インテンシティ法によ り, 燃焼騒音を把らえることが出来た。この新しい装置 は, 燃焼解析装置と並用するととによって燃焼の挙動解 析に活用できる.

なお，本研究にご協力いただいた，モービル石油(株), 小野測器 (株), 三菱化工機 (株), ディーゼル機器(株), 日本電装(株)の関係各位, ならびに長崎大学横山技官, 長崎大学熱流体研究室及び長崎総合科学大学熱工学研究 室の学生各位に謝意を表します.

\section{[質 疑 応 答]}

質問者 日立造船(株)技術研究所 水島一祐

〔質問〕（1）図 10 及び図 12 において，噴孔面積の減 少により, 噴射圧力は增大しているが，噴射率が減少す るため，噴射期間が延びている．それにもかかわらず, 燃料油滴の最適化により, 燃焼は改善され, 燃料消費は 低減されている.しかし，図 11 によれば，噴射後期に おいて, より高い噴射率となっており, 後然えが存在す
ると想像される. あし, 後燃えを取り除くことが出来れ ば，燃料消費率は，より低減されると考える．したがっ て, 燃費低減方法として, 噴射の初期に高噴射率を得る 様な reduced camの適用が非常に効果的であると考え る.

（2）著者らは，給気圧力を上昇することにより，燃料 油滴に熱エネルギを供給し，燃焼改善をしたと述べてい る. 一方, 図 13 に示されたように, 煙濃度は給気圧力 の上昇により減少している，すなわち，給気圧力の上昇 により, シリンダ内にトラップされた空気量が増大する から燃焼が改善されたと考えているがいかがか.

〔回答〕（1）噴孔面積の減少については貴意見のとお り. したがって, 本研究では, 噴射期間を延長すること なく, 噴射圧力を高めるために, カ厶速度及びプランジ ヤ径を増大した試験を行っている，すなわち，標準設計 の然料噴射ポンプ I に比べて，力ム速度のみを $14 \%$ 増大 したポンプII と, 力ム速度を $14 \%$, かつ, プランジャ径 を $5 \%$ 増大させたポンプIIIを試作した。

図A-1 は，ポンプI とポンプIII の燃料噴射モードの 比較を示す。噴射の初期において，ポンプ吕の噴射圧力 及び圧力上昇率はポンプ I より高く，噴射期間は短くな っている，その結果として，燃焼がわずかではあるが, 改善されており, ポンプ血を用いた場合, $100 \%$ 負荷で, 燃料消費率が $2.5 \mathrm{~g} / \mathrm{PSh}$, 煙濃度が 1.75 だけ減少してい る. 本論文で示した図 10 及び図 11 は，ポンプ四につい て，さらに，ノズル噴孔径の適合条件を調べたあのであ る.なお, 参考のため, 図 A-2 に, ポンプI とポンプ

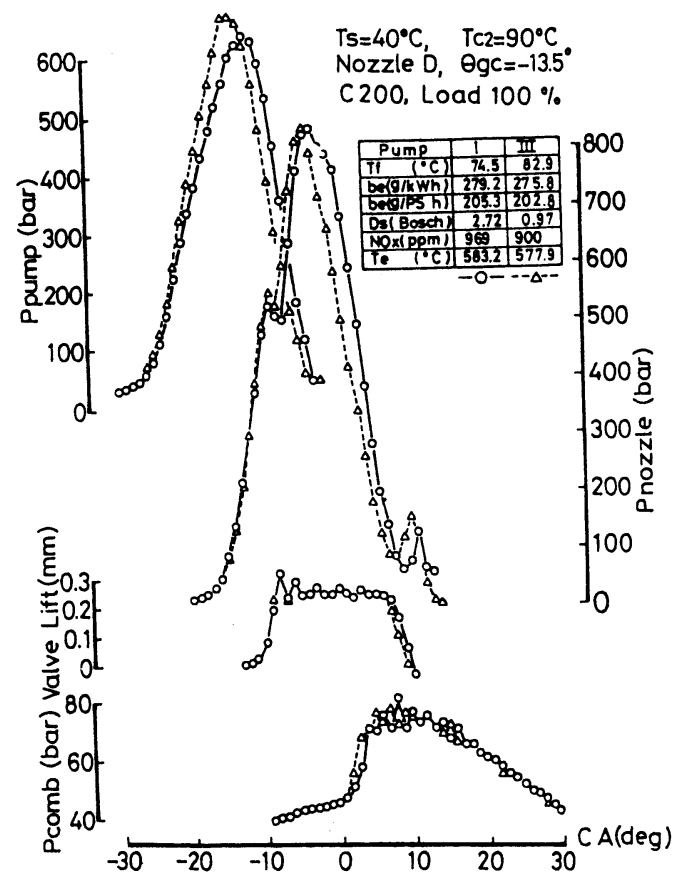

困 A-1 燃料噴射ポンプ変化 (燃料噴射モード) 
$\mathrm{Tf}=70^{\circ} \mathrm{C}, \mathrm{Ts}=40^{\circ} \mathrm{C}, \mathrm{Tc} 2=90^{\circ} \mathrm{C}$

Fuel: C200

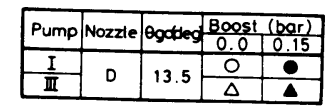

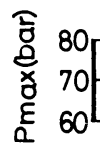

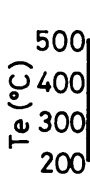

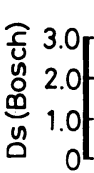
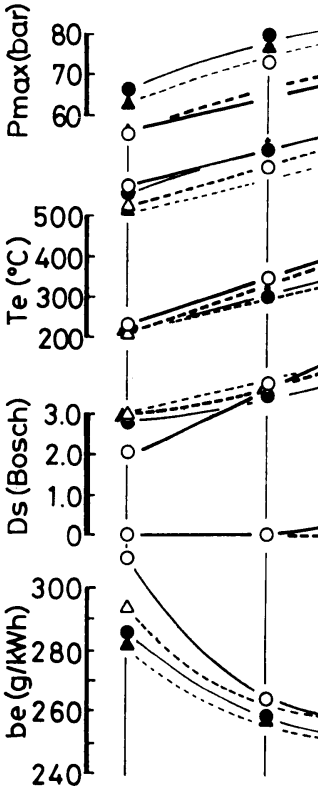

108

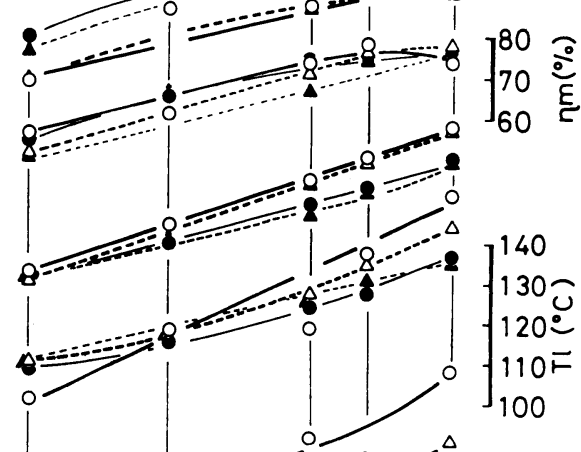

25
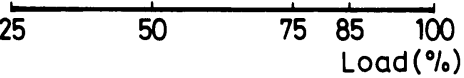

困 A-2 燃料噴射ポンプ変化（機関性能）

III の舶用特性曲線上での機関性能の比較を示す，燃料消 費率及び煙濃度は全域でポンプ吕の方が，ポンプI より 低くなっている.

（2）給気圧力を上昇させると、筒内圧力が上昇して着 火が早まり, 空気量の増大により, 燃焼自身が改善され, 燃焼終りも早くなる．ポンプ損失も低減される.

熱エネルギの供給という言葉の中には, 燃料噴霧の微 細化による全表面積の增大と空気量の増大，さらに，ス ワールの強さ等も含んでいる.

質問者 川崎重工業(株)神戸ディーゼル研究室 園田憲一

〔質問〕（1）図 2 において，ADO 35 とC200はセタ ン指数がそれぞれ 35,38 とほぼ同じであるにあかかわ らず, ADO 35 は, 着火性汇扔いて, 他の燃油之著しい 差異を示している。，一方，C200 は，セタン指数 50 の 舶用ディーゼル油 A40，あるいはセタン指数 60 の自動 車用ディーゼル軽油 ADO 60 上, 着火性において類似し ている．質問者の経験によれば，重油に関する限り，七 タン指数は，着火性の指標には必ずしあなりえない，図 2 の結果から判断すれば，同様なととが高速機関用の比 較的軽質の燃油について言えるかす知れない。特に, $\mathrm{ADO} 35$ のように FCC 軽油を含む燃油などの場合には, セタン指数が着火性の良い指標になりえないのではない
か. この点について，著者らの見解を知りたい，

着火時期を燃焼圧力の急激な上昇開始点として定義し てあるが，具体的には，図 7 において，着火時期をどこ にとるか. この方法と熱発生率曲線上で判断する方法で は，どちらが良いと考えられているか。

（2）本文において，給気温度を上昇させることにより， 着火及び初期燃焼は改善されるが，主燃焼は改善されな いと述べてある. このととは，非常に重要な結論なので， いま少し詳しく主燃焼について説明されたい,

（3）図 16 及び図 17 に示された $d P / d \theta$ とA.I.の関 係は非常に興味あるデータである.

$d P / d \theta$ を低減するために，着火促進剤を添加すれば 良いと聞いている，着火促進剂についての実験データが あれば，沶し頂きたい。同時に，着火促進剂の添加に よって， A. I. 及び $d P / d \theta$ がどのように変化するかに ついても，お教え下さい.

〔回答〕（1）図 2 からに示される着火時期の差が，必 ずしも，二種の燃油の着火遅れの差ではない。というの は，それぞれの燃油で，実噴射時期が，わずかに違って いるからである.

図 B-1にC/H比と着火遅れの関係を, 図 B-2 にセ タン指数と着火遅れの関係を示している. パラメータは 給気温度である。供試燃油の着火遅れは， C/ H 比，あ るいは, セタン指数之, 測定精度の範囲内で, 良い関係 が見られる.ただし，C 200 は，他の燃油に比べ，若干 異なった傾向を示している.

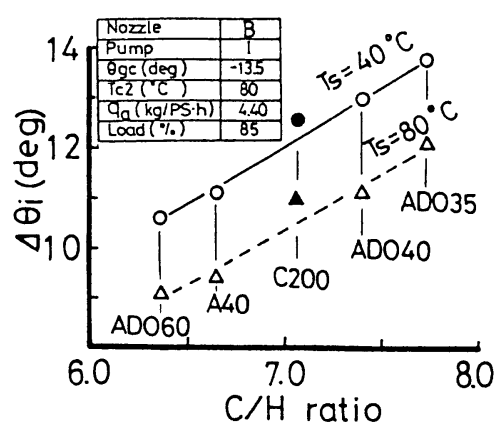

図 B-1 C/H比之着火遅れ

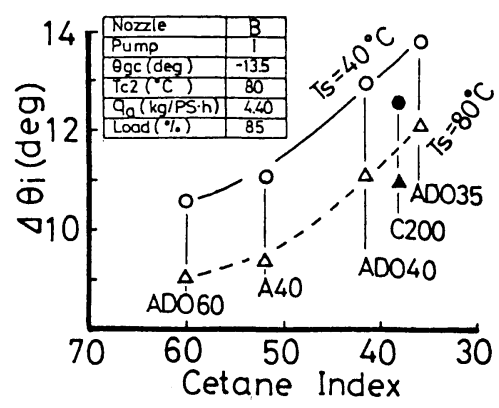

困 B-2 セタン指数と着火遅れ 


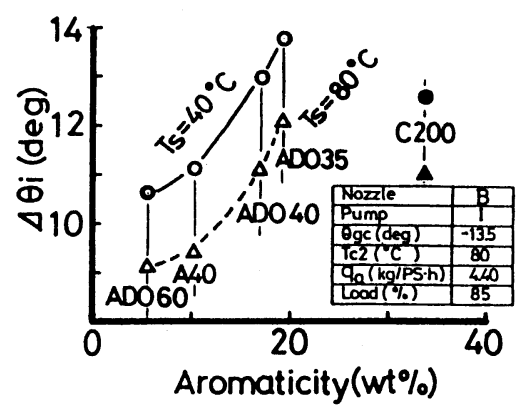

図 B-3 芳香族成分量と着火遅れ

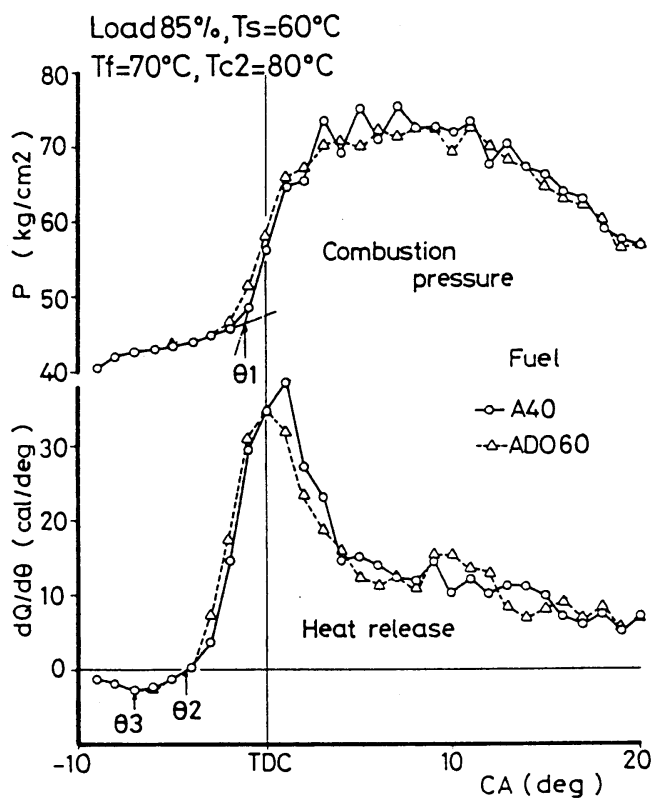

図 B-4 着火時期の定義

図B-3は，アルミナゲルクロマトグラフィによって 計測した芳香族の成分量と着火遅れの関係を示したが, C 200 の着火遅れは，芳香族の成分量が多いにあかかわ らず短い。着火はC 200 に含まれている数 $10 \%$ の 重油 の特性によって支配されるととを実証する興味ある事実 である.

同一運転条件下における，燃油A40 とADO60 の燃焼 圧力及び熱発生率のモードを, 図 B-4 亿示す. 図に示 すように，燃焼圧力の急激な上昇開始点 $\theta_{1}$ を着火時期 と定義している. 熱発生率の極小点 $\theta_{3}$ を着火点とする ことあ考えられるが, 熱発生率曲線上で, 極小点 $\theta_{3}$ は 明確につかみがたい，一方, 点 $\theta_{1}$ は測定したデータか ら, 直接しかも精度良く決定できる. したがって, 燃焼 挙動の全体を解析するために, 着火時期として, 点 $\theta_{1}$ を採用している.

（2）給気温度を上昇することは, 着火と初期燃焼の改 日本舶用機関学会誌 第 20 巻 第 5 号

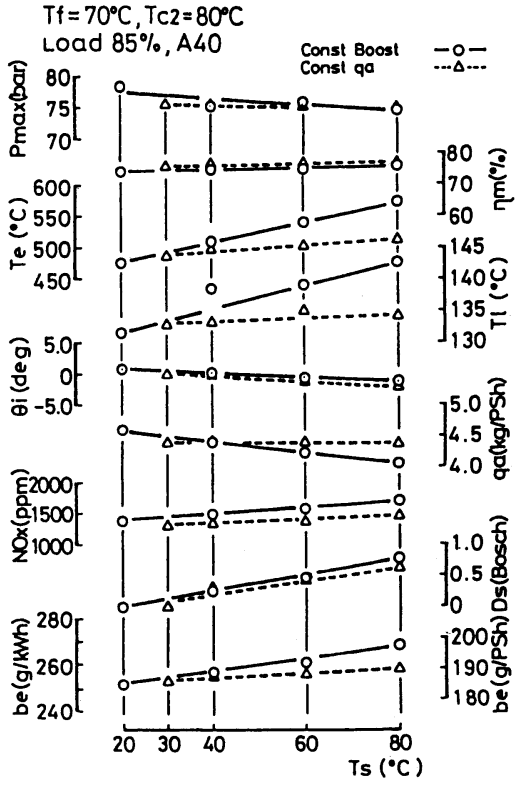

図 B-5 給気温度変化と機関性能

善対策であるが，主燃焼の改善にはならない，給気圧力 一定の条件下及び給気流量一定の条件で, 給気温度を, $30^{\circ} \mathrm{C}$ から $80^{\circ} \mathrm{C}$ まで変化させた場合の機関性能を図 B-5 に示す. 給気圧力一定の場合, 給気温度を上昇させると, 給気流量が減少するため, 燃料消費率と煙濃度は増加し ている. 給気流量一定の場合でさえ, 図 B-5 の破線で 示す様に, 燃料消費率と煙濃度は, わずかであるが増加 している.

（3）図 B-6は, 着火促進剤の添加割合を変化させた 場合の, 燃焼圧力及び圧力上昇率のモードを示す. 着火 促進剂の添加割合を增やしていくと, 着火遅れは短く なり, 圧力上昇率の最大值は減少する. 燃焼圧力モード の変化は, 図 7 に示した給気温度上昇の場合と, ほぼ同

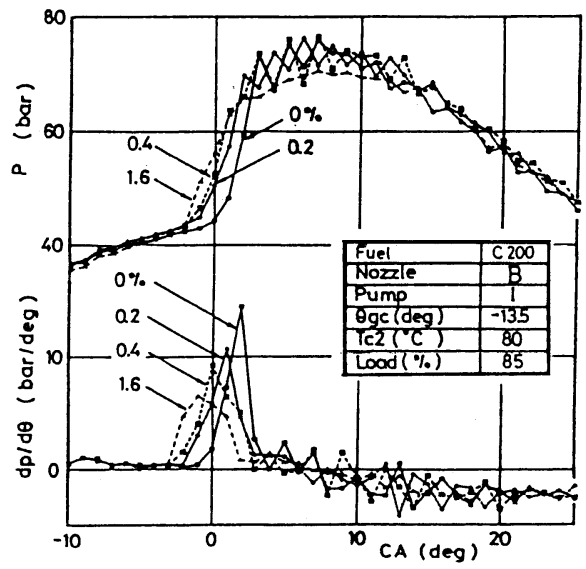

図 B-6 着火促進剂の添加割合と燃焼モード

昭和 60 年 5 月 
様の傾向を示す.

図 B-7に, 着火遅れの短縮度について, 給気温度上 昇と着火促進剂の添加量との比較を示す. 給気温度を $40^{\circ} \mathrm{C}$ 上昇させると, 着火遅れは, クランク角度で $1.7^{\circ}$ 短くなり, 着火促進剂を約 $0.4 \%$ 添加したのとほぼ同等

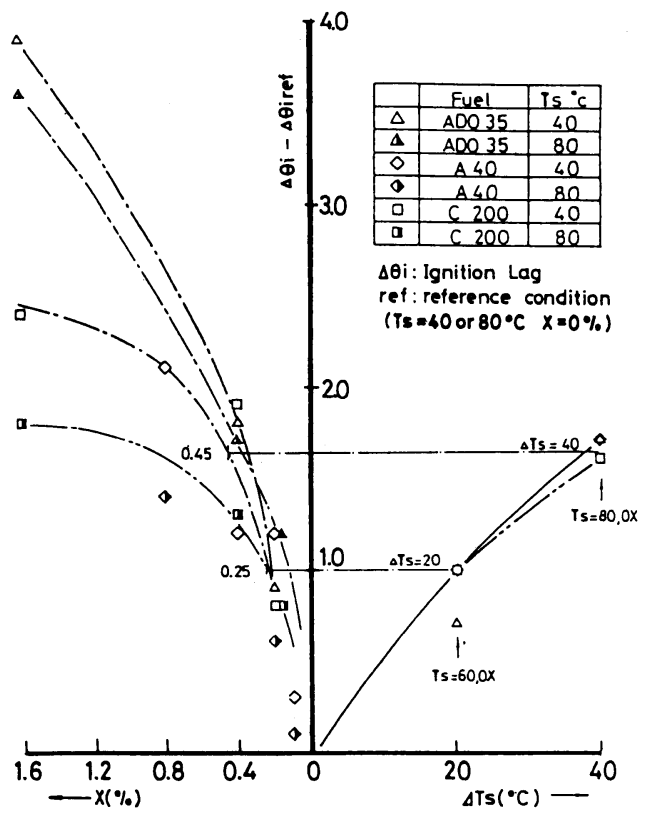

困B-7 着火遅れの比較

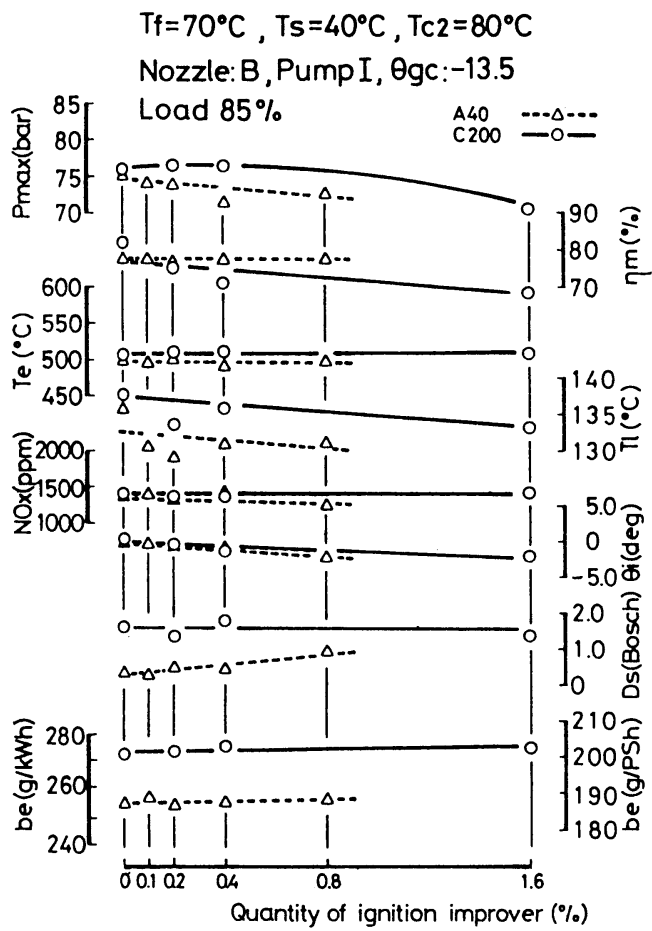

図 B-8 着火促進剂の添加割合と機関性能
である.

図 B-8は，着火促進剤の添加割合を変化したときの 機関性能を示す．着火促進剂を増やしても，燃料消費率 と煙濃度は，ほとんど変化しない，着火促進剤を利用す る方が，給気温度を上昇させるより，燃費節減の意味で は，より有効な手段である.

二連のマイクを使用する音響インテンシティ解析装置 CF-502 と燃焼解析装置 CB-366 と並用して, 燃焼の 挙動との関連で燃焼騒音を調べた。

図 B-9 は, 燃油 A40 に着火促進剂を添加させたとき の, A. I. 值の周波数特性を示す. 着火促進剂の添加割 合を増加させると， A. I. 值は周波数の全域で減少して いる.

図 B-10 は A.I.のオーバオール值と最大圧力上昇率 $(d P / d \theta)_{\max }$ との関係を示す. パラメータは, 気筒番号 である. 着火促進剤の添加割合を増加させると, 最大圧 力上昇率が低下し, A.I. 值む最大圧力上昇率と共に減

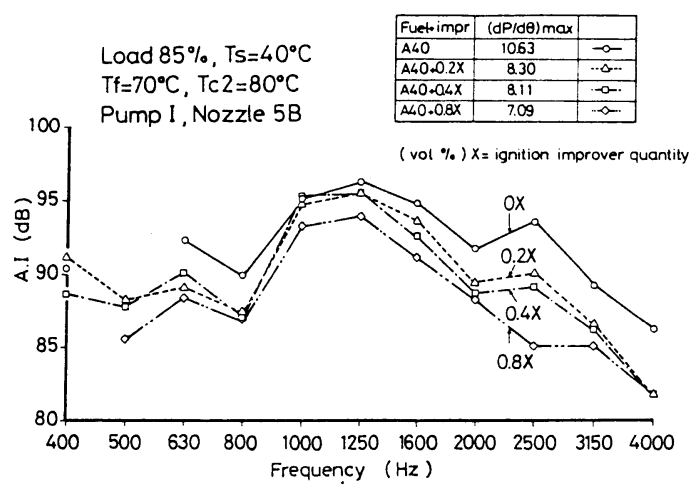

図 B-9 着火促進剂の添加割合と燃焼騒音の 周波数特性

Load $85 \%$, Ts $=40^{\circ} \mathrm{C}$, Tf $=70^{\circ} \mathrm{C}$, Tc $2=80^{\circ} \mathrm{C}$

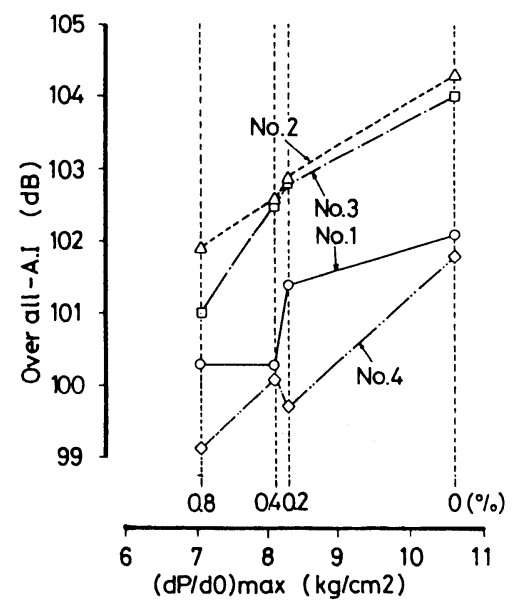

図 B-10 (dP/d $\theta)_{\max }$ とA.I. 值との相関 (添加促進剂添加割合変化) 
少する. なお， $\mathrm{ADO} 60$ の燃焼についても，同じ傾向が あった.

質問者 ヤンマーディーゼル(株)技術研究所 山田 正

〔質問〕（1）低質油燃焼における主要部品の耐久性に ついて.

低質油のテストにおいて, 次のことが重要と思うので, そのととに関して, 著者らの御意見, トラブルの経験及 びその改善対策を打聞かせ頂きたい.

a）ピストンリング，シリンダライナ及び排気弁の摩 耗

b）燃料噴射システムの耐久性，特に，燃料噴射ノズ ルについて

c）潤滑油の污れ

（2）低速，低負荷における燃焼性能について.

機関性能が $100 \%$ 負荷で, 最適化されるとすれば, 低 速, 低負荷での機関性能は, 白煙及び臭気の点で, 関心 事の一つ之なる，低質油燃焼試験において，低速，低負 荷での白煙及び臭気についての経験をお持ちか. あし， そうであれば，改善対策についてはいかがか.

〔回答〕（1）低質油の燃焼における耐久性において, 最も重要な問題は，ピストンリング, シリンダライナ及 び吸排気弁之弁座の腐食摩耗及びアブレイシブ摩耗であ る. これらの問題は, 燃焼の質と燃焼室壁の温度分布に よって決められる.

a）シリンダライナの温度分布については，無過給機 関 4A-1 の場合, 図 14 に示したように, 燃焼室壁を代 表する 24 点において, また, 過給機関 $3 \mathrm{AAC}-1$ の場合 は, 19 点で詳細に計測した。

図 15 は, トルクと回転数を広範囲に変化させたとき のトップリング位置より $22.7 \mathrm{~mm}$ 上の $\mathrm{A}_{1}$ 点で計測した ガス側ライナ温度を示す.

C 200 (改善)の場合, $\mathrm{A}_{1}$ 点の温度は, 冷却水温度が $10^{\circ} \mathrm{C}$ 高いにもかかわらず，高トルク域で， $\mathrm{A} 40$ のそれ より低い值を示している，過給機関の場合も，本文の図 21 に示したように，C200 (改善)では, シリンダライ ナ上部の表面温度は，A40 のそれよりむしろ低い值を示 している、したがって, 低質油燃焼時, 最も重要である ピストンリングとシリンダライナの摩耗, 燃焼室壁の熱 負荷とも，十分安全である. A 重油に匹敵する燃燒によ り，未燃炭素によるピストンリングとライナならびに排 気弁と弁座間のアブレイシブ摩耗の問題はない.

b）過給機関の場合, 低質油の燃焼を改善するため, カム速度, プランジャ径, ノズル噴孔面積の変更により, 噴射圧力を $800 \mathrm{bar}$ から $1000 \mathrm{bar}$ 高めた. 乙の場合 の燃料ポンプとノズルの耐久性については, 計測された 燃料噴射モードにおいて, キャビテーション現象がない ことを確認しており, 耐久性に関する問題はない。

c）良好な燃焼と適切な冷却システムのため，100\% 負荷のときのライナの円周方向の温度変化が $25^{\circ} \mathrm{C}$ 以下 であるので, 燃焼ガスのクランクケースへの漏れあ少な

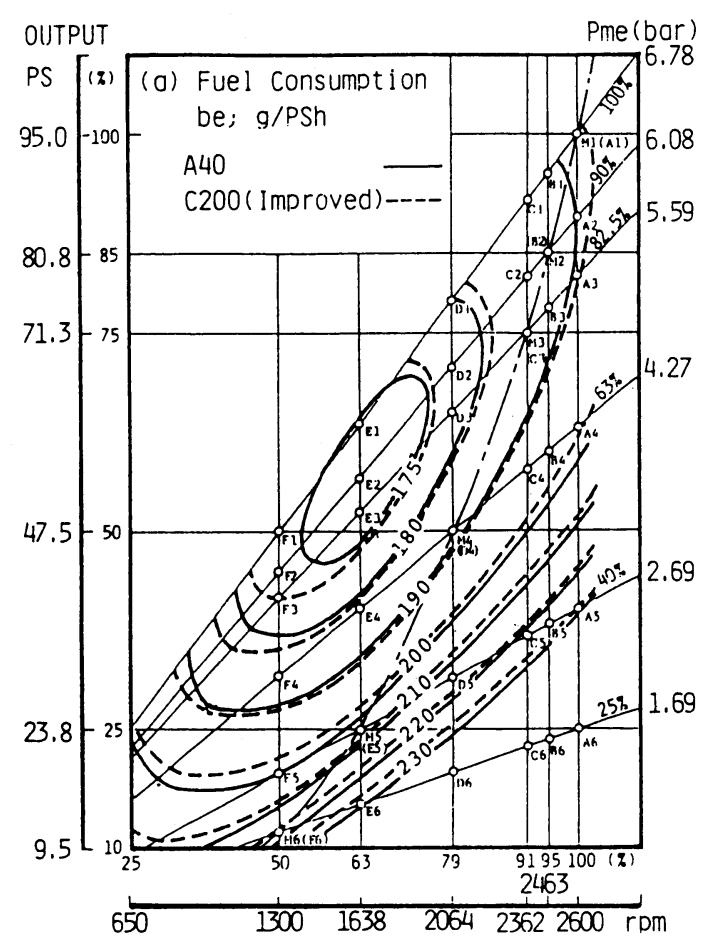

図 C-1 広範囲運転領域での機関性能 (無過給機関)

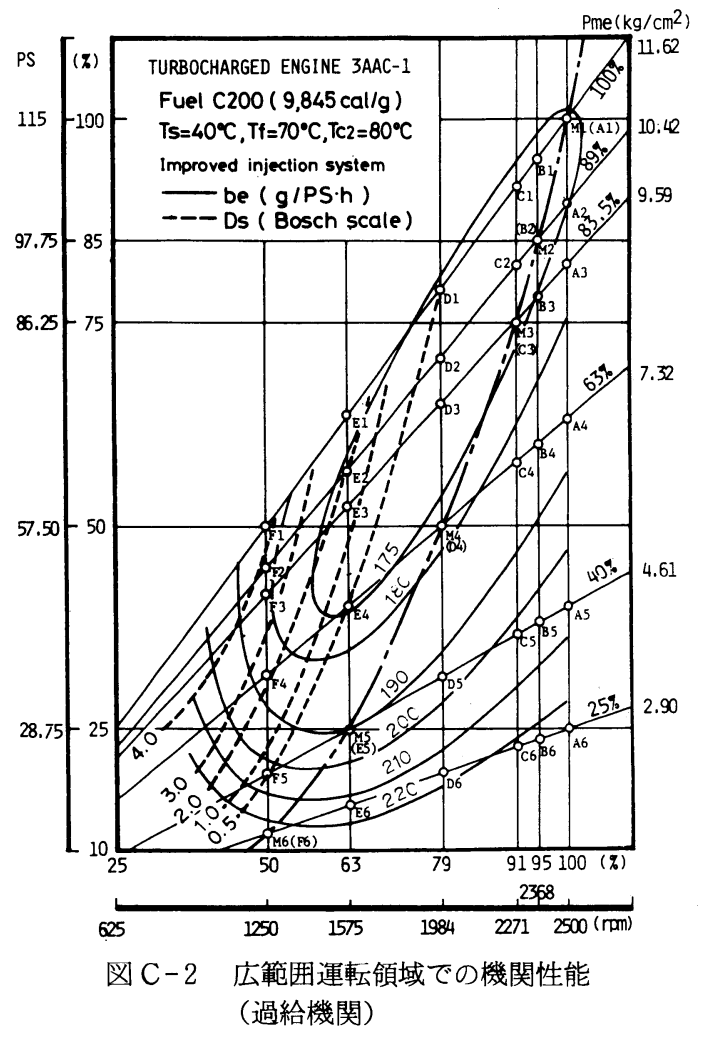

昭和 60 年 5 月 


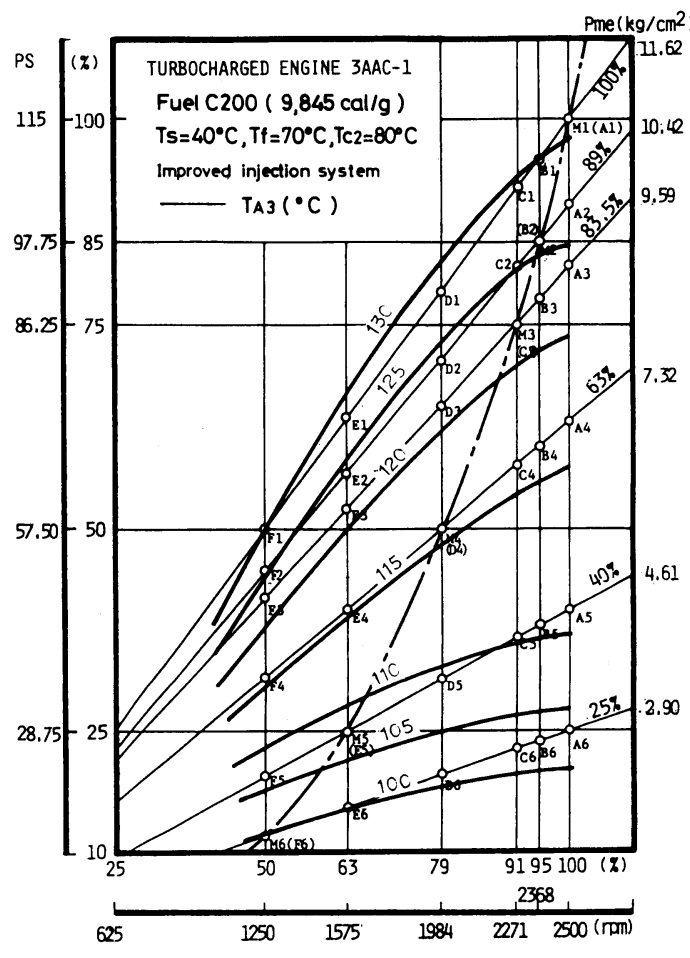

図 C-3 広範囲運転領域でのライナ温度 （トップリング位置）

く，かつ，ライナ温度のレベル自身が十分低いので，潤 滑油の劣化の恐れはないと考える.

（2）広範囲のトルク及び回転数の運転領域において, 機関性能と熱負荷との関係を確認した.

図 C-1 亿，無過給機関における A40 と C 200 (改善) の燃費の比較を示す．C200 の燃料消費率は高トルク域 では，A40のそれより良好である．低負荷域であ，C 200 の燃料消費率は，A40 とほとんど同じで，舶用特性曲線 上の $12.5 \%$ 負荷では $220 \mathrm{~g} / \mathrm{PSh}$ である.

図 C-2 は, 改善仕様の燃料噴射システムを持つ過給 機関の場合の広範囲運転領域における燃料消費率と煙濃 度について示しており, 全範囲で A40 の燃費より低い。

図 C-3 は，広範囲運転領域に扔ける過給機関のトッ プリング位置 $\mathrm{A}_{3}$ 点のシリンダライナ温度を示す. 改善対 策後の C 200 のライナ温度は, A 40 の場合之同様であ り， $12.5 \%$ 負荷のとき，トップリング位置でのライナ温 度は $100^{\circ} \mathrm{C}$ である。なお，上述の運転範囲においては， 白煙及び臭気の問題は全くない.

質問者 三井造船(株)技術開発本部 遠藤裕久

〔質問〕（1） FCC 法あるいはビスブレキング法等の 方法によって精製される分解軽油とブレンドするととに より，ディーゼル油のセタン価が減少するととが予想さ れる. 高速ディーゼル機関は，将来，セタン価の低い燃 油を使用する必要にせまられるであろうし，てのため着 火遅れの短縮が必要であろう.
貴論文の図 8 亿示されるように, 給気温度と燃油温度 の上昇は, 着火遅れの短縮に効果がある. 燃油温度が高 いと, 可燃混合気を形成する時間が短縮されることは理 解できる. しかし, 化学的着火遅れは燃油温度の上昇に よっては影響されない，ディーゼルノックは着火遅れ期 間中の可燃混合気の量に依存するので, 同一着火遅れの 場合, 可燃混合気の量が多いとディーゼルノックは改善 されない. 燃油温度変化試験における $d P / d \theta$ の変化を 示して下さい.

（2）運航経費節減のために，高速ディーゼル機関でも， 低質油を使用することは注目に值する.

低質油を燃焼する場合，種々の対策によって，燃焼性 能及び燃焼室壁の温度を良質の舶用ディーゼル油と同等 な值に保つととはできる.しかし，最む困難なととは， 舶用ディーゼル油で運転する時と同等な信頼性と耐久性 を維持することであり，したがって，潤滑油の污れ及 びピストンリングの摩耗等の試験が必要之思う. 信頼性 を維持するための対策に関して，てれから先，どのよう な計画を持持ちですか.

（3）燃料消費率における冷却水温度の効果は非常に大 きく, 熱効率の改善は冷却損失の減少に上ると結論づけ られている．しかし，燃料消費率の改善は燃焼自身の改 善とか, 摩擦損失の減少といった要素によるものと考え ている．乙の点について，著者らの見解を排きしたい． 〔回答〕（1）給気温度の上昇及び着火促進剂の少量の 添加により，着火の改善を行った[園田氏への回答 (3)を 参照了. 燃油温度を $80^{\circ} \mathrm{C}$ から $100^{\circ} \mathrm{C}$ まで変化させても, 粘度の差が少ないので, 着火を含め初期燃焼の差はほ己 んぞない，図 D-1 に燃焼圧力及び圧力上昇率のモード を示す.

（2）機関の信頼性と耐久性に関しては, 山田氏への回 答 (1) を参照されたい.

（3）冷却水温度の上昇による燃料消費率の低減の主体 は冷却損失の減少によるあのである. 冷却損失の中には 燃焼改善ならびに摩擦損失の低減も含む.

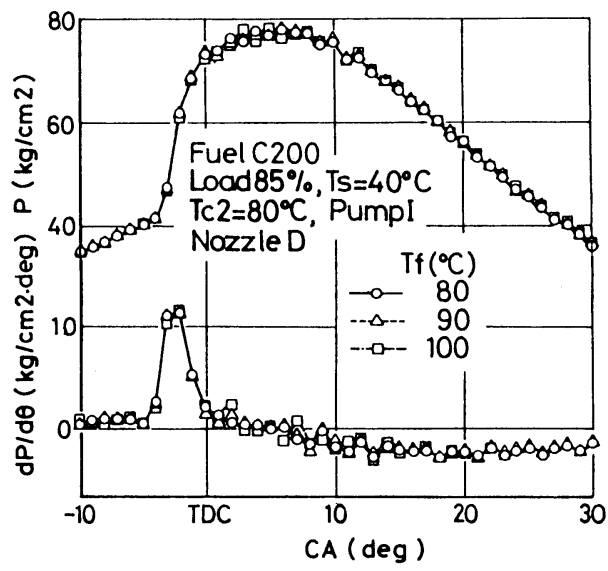

図 D-1 燃油温度変化と燃焼モート 